\title{
The Patterns of Stationary Activities during COVID-19 Distancing Relaxation: The elevated pedestrian network of Mong Kok, Hong Kong
}

\author{
Caterina Villani, Gianni Talamini, Zhijian Hu \\ Department of Architecture and Civil Engineering, \\ City University of Hong Kong, Tat Chee Avenue, Kowloon, Hong Kong SAR, China \\ cvillani2-c@my.cityu.edu.hk, gianntal@cityu.edu.hk, zhijianhu2-c@my.cityu.edu.hk \\ Tel : +85262244234
}

\begin{abstract}
COVID-19 is expected to impact the low-income groups' use of public space and related quality of life beyond the current pandemic outbreak. To what extent may the current pandemic affect the use of public space once some restrictions will be lifted? This study focuses on the migrant domestic workers' spatio-temporal changes in the patterns of public space use during social distancing relaxation period in Hong Kong. The findings highlight increase of individual leisure activities, decrease of density around informal food-production and of gathering group, comparatively to the pre-pandemic situation.
\end{abstract}

Keywords: Covid-19, public space, migrant domestic workers, behavioural mapping

eISSN: 2398-4287C 2020. The Authors. Published for AMER ABRA cE-Bs by e-International Publishing House, Ltd., UK. This is an open access article under the CC BYNC-ND license (http://creativecommons.org/licenses/by-nc-nd/4.0/). Peer-review under responsibility of AMER (Association of Malaysian Environment-Behaviour Researchers), ABRA (Association of Behavioural Researchers on Asians) and cE-Bs (Centre for Environment-Behaviour Studies), Faculty of Architecture, Planning \& Surveying, Universiti Teknologi MARA, Malaysia.

DOI: https://doi.org/10.21834/ebpj.v5i15.2461

\subsection{Introduction}

In response to the COVID-19 global pandemic, strategic policy measures have been implemented to limit human mobility patterns, restrict the use of public space (PS), introduce social distancing (SD) and several protective measures (PM) in numerous countries all over the world. To what extent may the current pandemic affect the use of PS once some restrictions will be lifted? While few studies forecast that a fundamental shift in the patterns of PS use may be possible, it is far more predicted an impact of the pandemic on vulnerable populations (Cole et al., 2020; Wade, 2020) and their access to and use of PS (Honey-Rosés et al., 2020). Vulnerable populations include women, children, the elderly, groups with a precarious job, education, health and housing conditions, ethnic minorities and migrants. Because of precarious living and economic conditions, migrant populations, particularly migrant domestic workers (MDWs), may encounter more barriers in respecting distancing, hygiene measures, and accessing health services and information in host countries (Castillo and Amoah, 2020; Liem et al., 2020).

Concurrently, among these vulnerable populations, social isolation may have mental health repercussions that are likely to impact their well-being, particularly in high-density settings with limited PS (Nobajas et al., 2020; Samuelsson et al., 2020; Zhang, 2020). For the MDWs, PS is often the only recreational open space for socially-oriented activities and can provide relief from inadequate living settings and weekly work-related fatigue in high-density environments as in the extreme case of Hong Kong (Villani et al., 2019; Villani and Talamini, 2020), where this study was set. By the end of June, this city was undergoing a lifting phase under the suppress and lift disease prevention strategy that allowed social distancing measures relaxation (HKSAR, 2020), thus may be considered a representative case for similar high-density environments' post-outbreak scenario.

eISSN: 2398-4287C 2020. The Authors. Published for AMER ABRA cE-Bs by e-International Publishing House, Ltd., UK. This is an open access article under the CC BYNC-ND license (http://creativecommons.org/licenses/by-nc-nd/4.0/). Peer-review under responsibility of AMER (Association of Malaysian Environment-Behaviour Researchers), ABRA (Association of Behavioural Researchers on Asians) and cE-Bs (Centre for Environment-Behaviour Studies), Faculty of Architecture, Planning \& Surveying, Universiti Teknologi MARA, Malaysia.

DOI: https://doi.org/10.21834/ebpj.v5i15.2461. 
At the time of writing this article, there is very limited empirical research providing evidence on the changes in PS use by vulnerable migrant urban populations, as the MDWs, during the post-pandemic outbreak period and specifically the SD relaxation phase. This evidence may provide insights for areas where future research will be critically needed during and after epidemics, as contingency PS planning and countermeasures for offsetting future needs and risks of vulnerable populations (Lai et al., 2020). Thus, this paper focusing on the MDWs' elevated pedestrian network (EPN) use in Hong Kong- attempts to consider which changes in PS use may arise and continue after the immediacy of the pandemic has passed. In what follows, the paper's aim and objectives are clarified; the literature review highlights recent studies forecasting post-pandemic changes in PS use, then the Hong Kong case study, methods and findings are presented. The discussion and conclusion sections compare the current findings with the pre-pandemic period and finally delineate urgent considerations for further studies.

\subsection{Aim and Objectives}

This article aims to assess how the COVID-19 prevention measures, including social distancing and personal protection measures, affect the MDWs' recreational use of PS during the SD relaxation period in the EPN of Mong Kok, Hong Kong. The objectives of the study are set as follows:

1) To measure the number of users and diversity of activities;

2) To expose the potential frequent surface and activity contact;

3) To measure the presence of PM, size and distance between groups of people.

\subsection{Literature Review}

A recent overview of early research related to COVID-19 and cities highlights that the thematic focus on the socio-economic impacts is still less investigated (Sharifi and Reza Khavarian-Garmsir, 2020). Historically, pandemics disproportionately impacted minorities due to pre-existing structural inequalities (idem). At the same time, pandemics have been related to drops in levels of mental health and wellbeing, particularly, limited social contact is highly associated with negative psychological outcomes (Wang et al., 2020). During the COVID-19 pandemic, empirical evidence showed that social connectedness seems to play crucial roles in psychological well-being (Sun et al., 2020), thus the importance of staying socially connected whilst respecting SD measures. Nevertheless, practising physical distancing might be challenging in high-density PS scarce environments, as in Asian cities (Wang et al., 2018). In these contexts, some public spaces -although residual, transitory and contested in nature- represented long-established setting for low-income groups' uses and social interactions before COVID-19 pandemic (Elsheshtawy, 2020; Martinez and Masron, 2020; Ostertag, 2016; Villani and Talamini, 2019).

Research addressing the impacts of COVID-19 on informal social interactions is critically needed (Honey-Rosés et al., 2020). At the same time, empirical evidence of the COVID-19 SD measures' impact on the vulnerable urban population's use of PS is scarce. At the time of writing, significant research indicates that the pandemic has been aggravating pre-existing inequalities, including the differential access to PS (Anguelovski et al., 2020). Notable research framed possible scenario of COVID-19 impact on the future PS and connected dynamics. Honey-Rosés et al. (2020) project that the COVID-19 impacts will include changes in:

1) The number of users

2) The temporal patterns of use

3) The variety of uses and activities

4) Use of face masks

5) The average group sizes

In the Post-COVID city, the total use of PS is expected to change, specifically fewer people might be observed in PS. This drop has repercussions also on how PS data will be gathered. The temporal patterns of PS occupation are expected to be similarly affected: peak hours will probably be avoided for retail, parks and public transport use, as physical distancing is expected to be more difficult in these locations. For what concerns the possible PS activities change, shopping and socializing (particularly informal social interactions), are most likely to be impacted by COVID-19. The first activity may be largely replaced by online retail. The informal social interactions among strangers in public space are expected to be limited, owing to the fear of contracting or spreading the virus. Widespread use of masks is likely to be a characteristic of public space users during the post-pandemic. Face mask use has been observed as soon as some tourist hotspots reopened in China and other Asian countries, where mask use is far more prevalent compared to the US (Eikenberry et al., 2020). Finally, a general aversion to large crowds may be possible. Revisiting past public life studies considering average group size in public may indicate a considerable shift (Honey-Rosés et al., 2020).

The present article attempts to fill the above-mentioned research gaps related to the change in the use of public space by a lowincome group during the COVID-19 SD. It aims to do so examining the use of one EPN in Hong Kong and comparing it with the prepandemic evidence. This space has been previously studied to host stationary activities performed primarily by MDWs engaging in conversation, food preparation, and food consumption (Villani and Talamini, 2020).

\subsection{Methodology}

The study area is Hong Kong, internationally recognized as one of the densest cities in the world with limited per-capita urban PS availability. The city was hit early in the pandemic development, by late January 2020 announced the first work at home recommendation and closure of public facilities (museums, libraries, sport centres). Before the pandemic, PS, in the form of EPN space was observed to 
be an established setting for large gatherings of MDW groups -mainly young women from Southeast Asia- every Sunday, which is their stipulated day off (Villani and Talamini, 2020; Wang, 2020). The EPN in the dense and PS scarce urban district of Mong Kok represents the use of this space typology during the pandemic; thus, is set as a case study (Yin, 2014). The EPN connects two main mass railway stations (Mong Kok and Mong Kok East), a connected shopping mall (MOKO mall) and spans with an L-shape across main traffic arteries, MK Road and Sai Yee Street (Fig. 1). As a main pedestrian mobility connector, access to this space has never been restricted during the pandemic. The functional design of the EPN is characterized by few elements: overhead covering, railings, garbage bins, escalators and lifts. Fig. 2 provides a view of the EPN.

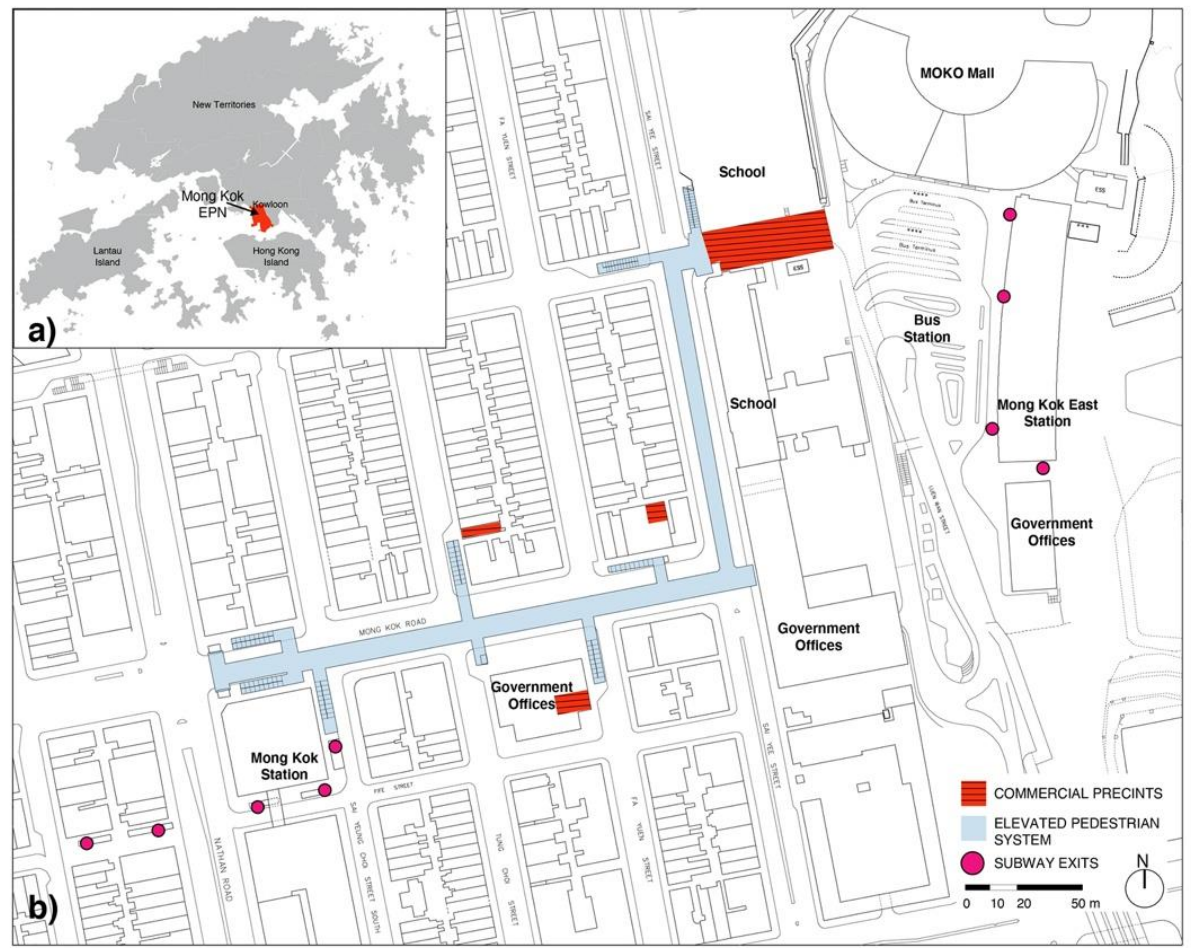

Fig. 1: a) Location of the EPN in Yau Tsim Mong District, Hong Kong B) Map of EPN (Source: (Villani and Talamini, 2020))

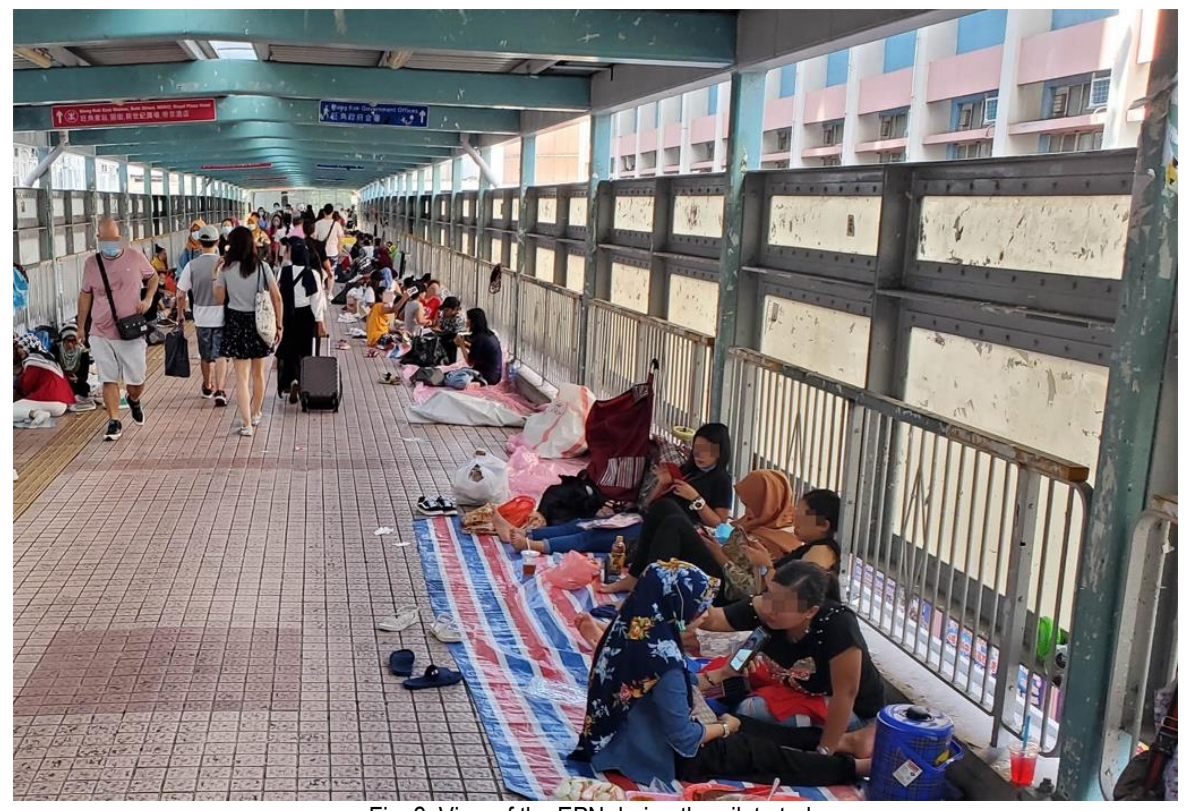

Fig. 2: View of the EPN during the pilot-study

\subsection{Environment-behaviour methods}

Honey-Rosés et al. (2020) stress the crucial need for observational fieldwork to understand the impacts of COVID-19 on informal social interactions. Thus, environment-behaviour methods (Cheshmehzangi and Heath, 2017; Goličnik Marušic, 2016; Hanan, 2017; 
Tammikakul and Raksawin, 2019), as videography and behavioural mapping, were adopted to analyze spatio-temporal patterns of use and associate them with specific EPN spatial features during the post-outbreak period.

\subsection{Data collection}

In order to compare the post-outbreak use of the EPN with pre-pandemic results, the data collection and analysis follows Villani and Talamini (2020). Stationary activities data were collected during three time-slots (morning, midday, afternoon) for one pilot-study during the beginning of July 2020. The three observations were video-recorded following the same walkthrough path along the EPN. After debriefing sessions aimed at categorizing the observed behaviours, the activities were recorded on a GIS platform (Tammikakul and Raksawin, 2019). On the same software the map of the EPN and the surrounding buildings was uploaded. The stationary activities were rendered through Dot-Distribution and Kernel Density maps. The behavioural data $(n=3068)$ were examined through geoprocessing and spatial analysis; descriptive statistics were reported in the findings' section.

\subsection{Methodology limitations}

The data were collected during one pilot study and reflect the occupancy during one weekend day and three periods. Due to manual geo-plotting intrinsic limitations, the activities reported might not wholly reflect the on-site condition. The objective is to identify whether some consistent post-pandemic outbreak stationary patterns of use exist in the Hong Kong skywalks; this analysis does not imply causality.

\subsection{Findings}

A total of 3068 stationary activities are visualized through the Dot Distribution Map (Fig. 3) to illustrate the quantity and density of people. The average stationary activities' number is 1022.7 (Table 1). Among them, the number of activities at midday is the largest (1190 observations), which is about $16 \%$ increase from the average activities' quantity. The population density shows a similar trend: the average occupancy of the entire EPN area is 0.28 person $/ \mathrm{m}^{2}$, and the highest value occurs during midday $\left(0.33 \mathrm{person} / \mathrm{m}^{2}\right)$.
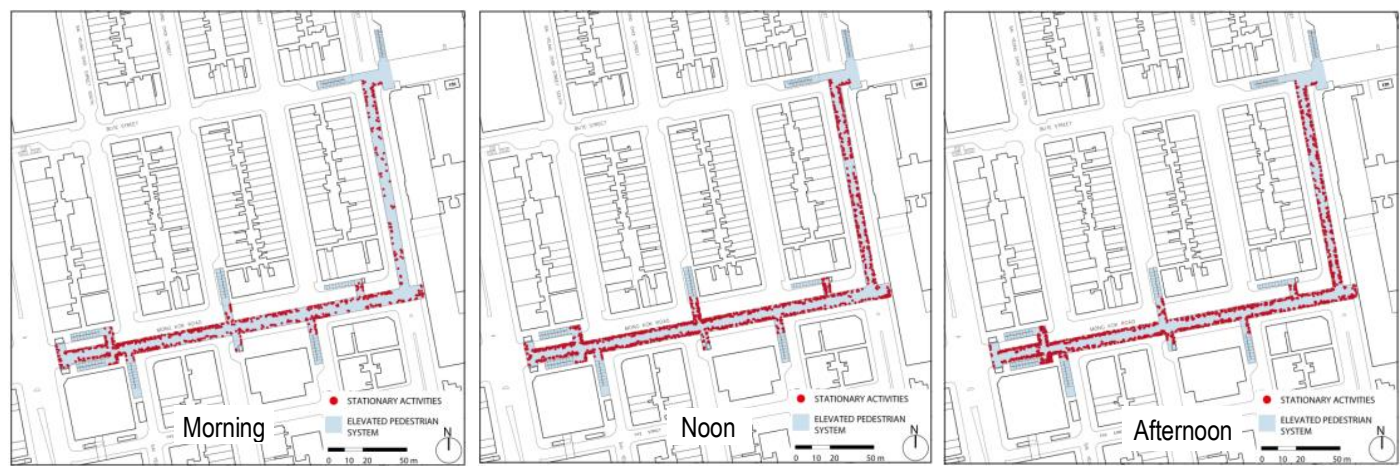

Fig. 3: Dot Distribution Map of stationary activities in the EPN

(Source: The authors)

Table 1. Activities and density per observation period

\begin{tabular}{lll}
\hline Period & Observations & Density [person/m2] \\
\hline Morning & 705 & 0.19 \\
Midday & 1190 & 0.33 \\
Afternoon & 1173 & 0.32 \\
Average & $\mathbf{1 0 2 2 . 7}$ & $\mathbf{0 . 2 8}$ \\
\hline \multicolumn{3}{c}{ (Source: The authors) }
\end{tabular}

Through the classification of activity types (Table 2), more detailed information can be obtained regarding the use of the EPN. Social activities $(60.0 \%)$ are the most common, followed by individual activities $(34.3 \%)$ and production-oriented activities $(5.7 \%)$. Among the social activities, chatting $(50.6 \%)$ is the most observed activity, while using the smartphone $(16.1 \%)$ accounts for the largest proportion of individual activities. MDWs tend to engage in hawking (3.4\%) -selling jewellery or snacks- as production-oriented activities.

Table 2. Proportion of activities per observation period

\begin{tabular}{|c|c|c|c|c|c|c|c|c|}
\hline \multirow[t]{2}{*}{ Period } & \multicolumn{8}{|c|}{ Individual } \\
\hline & Laying down & Standing & Packing & Self-care & Eating (alone) & $\begin{array}{c}\text { Using } \\
\text { smartphone }\end{array}$ & Smoking & Crafting \\
\hline Morning & $2.1 \%$ & $5.5 \%$ & $7.4 \%$ & $1.8 \%$ & $5.7 \%$ & $13.1 \%$ & $0.9 \%$ & $0.1 \%$ \\
\hline Midday & $3.8 \%$ & $3.3 \%$ & $2.3 \%$ & $1.3 \%$ & $4.4 \%$ & $17.6 \%$ & $0.6 \%$ & $0.3 \%$ \\
\hline Afternoon & $5.6 \%$ & $3.8 \%$ & $2.5 \%$ & $0.7 \%$ & $2.4 \%$ & $17.8 \%$ & $0.6 \%$ & $0.1 \%$ \\
\hline Average & $3.8 \%$ & $4.2 \%$ & $4.0 \%$ & $1.2 \%$ & $4.1 \%$ & $16.1 \%$ & $0.7 \%$ & $0.2 \%$ \\
\hline Total & \multicolumn{8}{|c|}{$34.3 \%$} \\
\hline Period & \multicolumn{6}{|c|}{ Social } & \multicolumn{2}{|c|}{ Production oriented } \\
\hline
\end{tabular}




\begin{tabular}{|c|c|c|c|c|c|c|c|c|}
\hline & Chatting & Praying & $\begin{array}{c}\text { Taking a } \\
\text { Selfie }\end{array}$ & $\begin{array}{c}\text { Sharing } \\
\text { food }\end{array}$ & $\begin{array}{c}\text { Talking on the } \\
\text { phone }\end{array}$ & Give care & $\begin{array}{c}\text { Preparing } \\
\text { food }\end{array}$ & $\begin{array}{c}\text { Hawking (or } \\
\text { selling) }\end{array}$ \\
\hline Morning & $38.4 \%$ & $0.3 \%$ & $0.6 \%$ & $12.8 \%$ & $2.4 \%$ & $0.3 \%$ & $4.1 \%$ & $4.5 \%$ \\
\hline Midday & $55.4 \%$ & $0.1 \%$ & $0.3 \%$ & $4.8 \%$ & $1.8 \%$ & $0.3 \%$ & $1.5 \%$ & $2.6 \%$ \\
\hline Afternoon & $58.0 \%$ & $0.1 \%$ & $0.1 \%$ & $3.0 \%$ & $1.3 \%$ & $0.1 \%$ & $1.2 \%$ & $2.9 \%$ \\
\hline Average & $50.6 \%$ & $0.2 \%$ & $0.3 \%$ & $6.9 \%$ & $1.8 \%$ & $0.2 \%$ & $2.3 \%$ & \multirow[b]{2}{*}{$5.7 \%$} \\
\hline Total & \multicolumn{7}{|c|}{$60.0 \%$} & \\
\hline
\end{tabular}

(Source: The authors)

\subsection{Potential surface and activities contact}

The distribution of the population is spatially concentrated near specific environmental features. The EPN area is divided into part 1 and part 2, and the $2 \mathrm{~m}$ buffer from the railing line (Fig. 4). Besides, the 1-meter buffer from the production-oriented activities' location and the garbage bins are also analyzed to assess people's choice of activity location. The density of part $1\left(0.32 \mathrm{person} / \mathrm{m}^{2}\right)$ is higher than the part $2\left(0.23\right.$ person $\left./ \mathrm{m}^{2}\right)$ (Table. 3). Stationary activities cluster near the railing area $\left(0.63\right.$ person $\left./ \mathrm{m}^{2}\right)$ and tend to stay away from the garbage bins $\left(0.32\right.$ person $\left./ \mathrm{m}^{2}\right)$. Moreover, the density of the production-oriented area $\left(0.57 \mathrm{person} / \mathrm{m}^{2}\right)$ is slightly higher than the average activities' density (Table 3.).

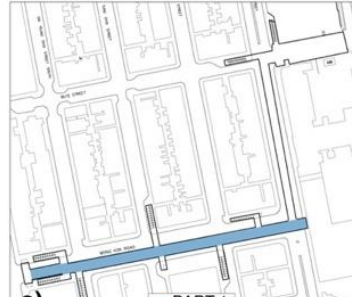

a)

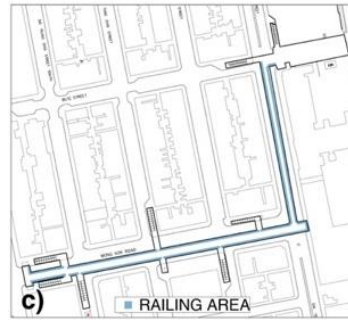

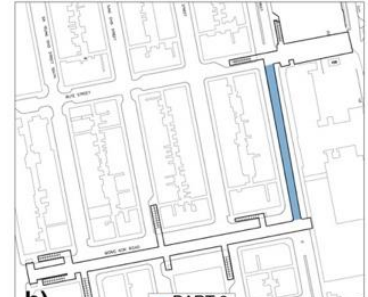

b)

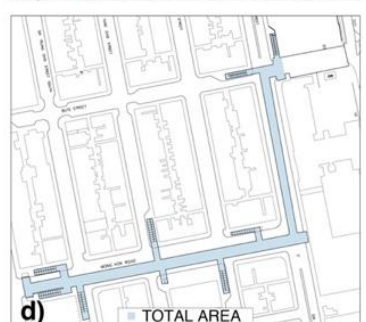

Fig. 4: a) the EPN part 1. b) The EPN part 2. c) The railing space (2 $\mathrm{m}$ offset) d) Total EPN area (Source: The authors)

Table 3. Activities' density per spatial feature

\begin{tabular}{lllllll}
\hline & Part 1 & Part 2 & Railing area & $\begin{array}{l}\text { Food } \\
\text { preparation } \\
\text { area }\end{array}$ & $\begin{array}{l}\text { Garbage bins } \\
\text { area }\end{array}$ & Total Area \\
\hline Morning & 0.25 & 0.09 & 0.42 & 0.51 & 0.21 & 0.19 \\
Noon & 0.36 & 0.28 & 0.73 & 0.61 & 0.43 & 0.33 \\
Afternoon & 0.35 & 0.31 & 0.73 & 0.58 & 0.32 & 0.32 \\
Average & $\mathbf{0 . 3 2}$ & $\mathbf{0 . 2 3}$ & $\mathbf{0 . 6 3}$ & $\mathbf{0 . 5 7}$ & $\mathbf{0 . 3 2}$ & $\mathbf{0 . 2 8}$ \\
\hline
\end{tabular}

(Source: The authors)

\subsection{Presence of PM, size and distance between groups of people}

During the COVID-19 period, the use of masks and precautions as hand hygiene or wearing disposable gloves are commonly used measures to limit the risk of contracting and spreading of the virus (Table 4). In the EPN area, the proportion of stationary users using masks is $11 \%$, while users wearing gloves are $7.4 \%$. There are fewer stationary users wearing masks at noon $(9.2 \%)$.

Table 4. Proportion of mask and precaution

\begin{tabular}{lll}
\hline Period & Mask & Precaution (glove) \\
\hline Morning & $11.9 \%$ & $13.3 \%$ \\
Midday & $9.2 \%$ & $4.6 \%$ \\
Afternoon & $11.9 \%$ & $4.2 \%$ \\
Average & $\mathbf{1 1 . 0 \%}$ & $\mathbf{7 . 4 \%}$ \\
\hline \multicolumn{3}{c}{ (Source: The authors) }
\end{tabular}

Through geoprocessing and descriptive statistics, Table 5 shows the average size of the users' groups. Dividing the total number of people by the number of groups gives an average of approximately 2.24 people in each group. By using proximity analysis to calculate the distance between all activities-points and their closest neighbour, the average distance of $0.83 \mathrm{~m}$ can be obtained (Table 6). We need to note that at the time of data collection, the maximum group size allowed by the government's guidelines was 50 people, and the distance among people was at least $1 \mathrm{~m}$ recommended safe distance. Since there are fewer people in the morning, the group size is smaller (1.98 people) and people are farther away $(0.96 \mathrm{~m})$. 
Table 5. Group size

\begin{tabular}{llll}
\hline Period & $\begin{array}{l}\text { Number of } \\
\text { people }\end{array}$ & groups & $\begin{array}{l}\text { People per } \\
\text { group }\end{array}$ \\
\hline Morning & 705 & 356 & 1.98 \\
Noon & 1190 & 507 & 2.35 \\
Afternoon & 1173 & 489 & 2.40 \\
Average & $\mathbf{1 0 2 2 . 7}$ & $\mathbf{4 5 0 . 7}$ & $\mathbf{2 . 2 4}$ \\
\hline \multicolumn{4}{c}{ (Source: The authors) }
\end{tabular}

Table 6. Distance between people

\begin{tabular}{llll}
\hline Period & Minimum $(\mathrm{m})$ & Maximum $(\mathrm{m})$ & Average $(\mathrm{m})$ \\
\hline Morning & 0.31 & 6.24 & 0.96 \\
Noon & 0.25 & 4.02 & 0.77 \\
Afternoon & 0.34 & 3.82 & 0.77 \\
Average & $\mathbf{0 . 3 0}$ & $\mathbf{4 . 6 9}$ & $\mathbf{0 . 8 3}$ \\
\hline \multicolumn{4}{c}{ (Source: The authors) }
\end{tabular}

\subsection{Discussion}

We estimated an overall decrease in the MDWs activities compared to the pre-pandemic observations reported in Villani and Talamini (2020), collected during afternoon time. The afternoon stationary activities number (1173) and activities density $\left(0.32\right.$ person $\left./ \mathrm{m}^{2}\right)$ decreased by $20.6 \%$ and $22 \%$ respectively in the SD relaxation phase compared to pre-pandemic findings in the same EPN (Villani and Talamini, 2020). Compared with the pre-pandemic period, chatting (58\%, total $680 \mathrm{MDWs)} \mathrm{during} \mathrm{the} \mathrm{post-outbreak} \mathrm{period} \mathrm{is}$ drastically lower than before pandemic $(87 \%$, average $1292.3 \mathrm{MDWs})$, while the percentage of sharing-food activity slightly increased from the average $31 \mathrm{MDWs}-2 \%$ - (pre-pandemic) to 35 users, $3 \%$. At the same time, individual activities increased from $8 \%$ (average 108.4 MDWs) during pre-pandemic to $33.4 \%$ (total 392) during the pandemic. In particular, we observed a higher percentage of migrants laying down relaxing alone during pandemic $(5.63 \%)$. This may indicate that the preference for activities shifted from more informal conversation time (pre-pandemic) to be limited to individual leisure activities that do not involve gathering, but resting activities. Patterns of spatial occupancy changed, with the slightly lower occupation of spaces that may potentially lead to infected surface contact as railings ( $24 \%$ density decrease). Additionally, density around informal food-production -freshly made meals- $\left(0.58 \mathrm{person} / \mathrm{m}^{2}\right) \mathrm{dropped}$ by $53.6 \%$ compared to pre-pandemic. These patterns may indicate MDWs preference to avoid possible surface contact or exchange. Masks were not widely used, and fewer stationary users are wearing these at noon (9.2\%). This may be due to the higher temperature and eating activities, while current research indicates that even in lower transmission settings, as PSs, the use of face masks may contribute to reducing transmission (Maclntyre and Hasanain, 2020). The public are usually limiting the period during which they wear masks to the duration of essential activities in PS (Szepietowski et al., 2020). We need to note that MDWs tend to gather in PS for a prolonged period of time while they perform non-essential activities; thus the use of face mask might become challenging. Lower use of masks may also indicate that MDWs face challenges in accessing this protective measure (Liem et al., 2020). Regarding the proportion of users wearing gloves, we need to note that this practice was already observed before the pandemic and is linked to the cultural habits of eating food (Constable, 2009). Finally, a significant change was observed in the drop in the number of people per group (less than 3 ), while before the pandemic this was observed to be around 6-8 people. This drop might indicate an ongoing trend in limiting and reducing large gathering groups. MDWs tend to gather with friends or family from the same region or sharing the same language (Law, 2002), limiting the group size might lead to fewer social interactions.

\subsection{Conclusion and Recommendations}

Before the pandemic, the central role of socializing in PS for migrant workers' mental health and well-being was recognized. During the post-outbreak, the effects of the observed drop in stationary -particularly social- activities may lead to alarming well-being repercussions, thus need to be further researched. In light of the long-term use that MDWs established in this and other similar spaces (Villani and Talamini, 2021) the post-outbreak decrease in use might also lead to public space and placemaking changes. The findings shed new light on the necessity of including vulnerable groups considerations to inform urban planning and policymaking in a postpandemic response. In the past, pandemics have resulted in scarce post-pandemic actions aiming at addressing the needs of lowincome groups (Sharifi and Reza Khavarian-Garmsir, 2020).

Nevertheless, in the aftermath of the crisis, cities may need some critical challenges, as spatial justice, to be addressed in the path towards an inclusive planning agenda for low-income groups (Jon, 2020). As a first step, 'street experiments' (Bertolini, 2020) may be implemented in high-density cities by prioritising the provision of space in low income groups' established gathering location. New directions for research may include the extension of the current research to the use of dispersed, local PS (Chu and Catalan, 2020), interviews with MDWs' and extension of the observation days to better capture the PS use and selection choice during the pandemic evolution. Further analysis may also associate environmental factors to stress levels (Jiang et al., 2019).

\section{Acknowledgements}

This research was financially supported by a grant from the City University of Hong Kong (Project No. 6000645). We would like to thank Zhang Junlin for his assistance during the data collection. 


\section{Paper Contribution to Related Field of Study}

Empirical evidence of a change in behavioral patterns associated with the COVID-19 impact on social norms is as follows:

1) Overall decrease of around $20 \%$ in stationary activities number and decrease of group size compared to pre-pandemic.

2) Increase in individual activities, particularly resting and using the smartphone.

3) Patterns of spatial occupancy changed with lower density associated with railings and informal food-production area.

4) Future research directions for further analysis were proposed.

5) This study is the first environment-behaviour study on migrant domestic workers' use of public space during social distancing relaxation.

\section{References}

Anguelovski, I., Brand, A.L., Connolly, J.J.T., Corbera, E., Kotsila, P., Steil, J., Garcia-Lamarca, M., Triguero-Mas, M., Cole, H., Baró, F., Langemeyer, J., del Pulgar, C.P., Shokry, G., Sekulova, F., Argüelles Ramos, L., (2020). Expanding the Boundaries of Justice in Urban Greening Scholarship: Toward an Emancipatory, Antisubordination, Intersectional, and Relational Approach. Ann. Am. Assoc. Geogr. 110, 1743-1769. https://doi.org/10.1080/24694452.2020.1740579

Bertolini, L., (2020). From "streets for traffic" to "streets for people": can street experiments transform urban mobility? Transp. Rev. 40, 734-753. https://doi.org/10.1080/01441647.2020.1761907

Castillo, R., Amoah, P.A., (2020). Africans in post-COVID-19 pandemic China: is there a future for China's 'new minority'? Asian Ethn. 21, 560-565. https://doi.org/10.1080/14631369.2020.1773760

Cheshmehzangi, A., Heath, T., (2017). Effects of Temporary Markets on Spatial Inter-relations: A behavioural analysis of a public realm in the UK. J. ASIAN Behav. Stud. 2, 41. https://doi.org/10.21834/jabs.v2i3.190

Chu, C., Catalan, M., (2020). Beyond the Sunday Spectacle: Foreign Domestic Workers and Emergent Civic Urbanisms in Hong Kong., in: Cho, I.S., Kriznik, B., Hou, J. (Eds.), Emerging Civic Urbanisms in East Asia. Amsterdam University Press, Amsterdam.

Cole, H.V.S., Anguelovski, I., Baró, F., García-Lamarca, M., Kotsila, P., Pérez del Pulgar, C., Shokry, G., Triguero-Mas, M., (2020). The COVID-19 pandemic: power and privilege, gentrification, and urban environmental justice in the global north. Cities Heal. 1-5. https://doi.org/10.1080/23748834.2020.1785176

Constable, N., (2009). Migrant workers and the many states of protest in Hong Kong. Crit. Asian Stud. 41, 143-164. https://doi.org/10.1080/14672710802631202

Eikenberry, S.E., Mancuso, M., Iboi, E., Phan, T., Eikenberry, K., Kuang, Y., Kostelich, E., Gumel, A.B., (2020). To mask or not to mask: Modeling the potential for face mask use by the general public to curtail the COVID-19 pandemic. Infect. Dis. Model. 5, 293-308. https://doi.org/10.1016/j.idm.2020.04.001

Elsheshtawy, Y., (2020). Urban enclaves and transient cosmopolitanism: Scenes from Abu Dhabi and Dubai. City. https://doi.org/10.1080/13604813.2020.1843279

Goličnik Marušic, B., (2016). Discrepancy between likely and actual occupancies of urban outdoor places. Urban For. Urban Green. 18, 151-162. https://doi.org/10.1016/j.ufug.2016.06.001

Hanan, H., (2017). Every Day Practices and Experiential Urban Space. Asian J. Environ. Stud. 2, 27. https://doi.org/10.21834/aje-bs.v2i5.220

HKSAR, (2020). Government announces latest disease prevention measures.

Honey-Rosés, J., Anguelovski, I., Chireh, V.K., Daher, C., Konijnendijk van den Bosch, C., Litt, J.S., Mawani, V., McCall, M.K., Orellana, A., Oscilowicz, E., Sánchez, U., Senbel, M., Tan, X., Villagomez, E., Zapata, O., Nieuwenhuijsen, M.J., (2020). The impact of COVID-19 on public space: an early review of the emerging questions design, perceptions and inequities. Cities Heal. 1-17. https://doi.org/10.1080/23748834.2020.1780074

Jiang, B., Wang, H., Larsen, L., Bao, F., Li, Z., Pryor, M., (2019). Quality of sweatshop factory outdoor environments matters for workers' stress and anxiety: A participatory smartphone-photography survey. J. Environ. Psychol. 65, 101336. https://doi.org/10.1016/j.jenvp.2019.101336

Jon, I., (2020). A manifesto for planning after the coronavirus: Towards planning of care. Plan. Theory 19, 329-345. https://doi.org/10.1177/1473095220931272

Lai, K.Y., Webster, C., Kumari, S., Sarkar, C., (2020). The nature of cities and the Covid-19 pandemic. Curr. Opin. Environ. Sustain. https://doi.org/10.1016/j.cosust.2020.08.008

Law, L., (2002). Defying Disappearance: Cosmopolitan Public Spaces in Hong Kong. Urban Stud. 39, 1625-1645. https://doi.org/10.1080/00420980220151691

Liem, A., Wang, C., Wariyanti, Y., Latkin, C.A., Hall, B.J., (2020). The neglected health of international migrant workers in the COVID-19 epidemic. The Lancet Psychiatry 7, e20. https://doi.org/10.1016/S2215-0366(20)30076-6

Macintyre, C.R., Hasanain, S.J., (2020). Community universal face mask use during the COVID 19 pandemic-from households to travellers and public spaces. J. Travel Med. 27, 1-3. https://doi.org/10.1093/jtm/taaa056

Martinez, R., Masron, I.N., (2020). Jakarta: A city of cities. Cities 106, 102868. https://doi.org/10.1016/j.cities.2020.102868

Nobajas, A., Casas, J.G. i, Agusti, D.P. i, Peacock, A.J., (2020). Lack of sufficient public space can limit the effectiveness of COVID-19's social distancing measures. medRxiv 2020.06.07.20124982. https://doi.org/10.1101/2020.06.07.20124982

Ostertag, E., (2016). Transitory community hubs: How temporary migration transforms a neighbourhood in Singapore. City 20, 116-129. https://doi.org/10.1080/13604813.2015.1096058 
Samuelsson, K., Barthel, S., Colding, J., Macassa, G., Giusti, M., (2020). Urban nature as a source of resilience during social distancing amidst the coronavirus pandemic. https://doi.org/10.31219/osf.io/3wx5a

Sharifi, A., Reza Khavarian-Garmsir, A., (2020). The COVID-19 pandemic: Impacts on cities and major lessons for urban planning, design, and management. Sci. Total Environ. 749, 142391. https://doi.org/10.1016/j.scitotenv.2020.142391

Sun, R., Balabanova, A., Bajada, C.J., Liu, Y., Kriuchok, M., Voolma, S.-R., Đurić, M., Mayer, C.-H., Constantinou, M., Chichua, M., Li, C., Foster-Estwick, A., Borg, K., Hill, C., Kaushal, R., Diwan, K., Vitale, V., Engels, T., Amin, R., Ursu, I., Fadhlia, T.N., Wu, Y., Sekaja, L., Hadchity, M., Deak, A., Sharaf, S., Figueras, P., Kaziboni, A., Whiston, A., loumpa, K., Montelongo, A., Pauw, L.S., Pavarini, G., Vedernikova, E., Vu, T.-V., Nummenmaa, L., Cong, Y.-Q., Nikolic, M., Olguin, A., Hou, W.K., Israelashvili, J., Koo, H., Khademi, S., Ukachukwu, C.G., Juma, D.O., Kamiloglu, R.G., Makhmud, A., Lunga, P.S., Rieble, C., Rizwan, M., Helmy, M., Vuillier, L., Manokara, K., Quezada, E.C., Tserendamba, D., Yoshie, M., Du, A., Philip-Joe, K., Kúld, P.B., Damani, K., Osei-Tutu, A., Sauter, D., (2020). Psychological wellbeing during the global COVID-19 outbreak. https://doi.org/10.31234/osf.io/r7xaz

Szepietowski, J.C., Matusiak, Ł., Szepietowska, M., Krajewski, P.K., Białynicki-Birula, R., (2020). Face mask-induced itch: A self-questionnaire study of 2,315 responders during the COVID-19 pandemic. Acta Derm. Venereol. 100, 1-5. https://doi.org/10.2340/00015555-3536

Tammikakul, P., Raksawin, K., (2019). The Pattern of Activity Analysis by GIS in Chiang Mai Public Plaza, Thailand. Asian J. Environ. Stud. $4,30$. https://doi.org/10.21834/aje-bs.v4i13.346

Villani, C., Talamini, G., (2020). Pedestrianised streets in the global neoliberal city: A battleground between hegemonic strategies of commodification and informal tactics of commoning. Cities 108, 102983. https://doi.org/10.1016/j.cities.2020.102983

Villani, C., Talamini, G., (2020). Socialising on a Skywalk: How Hong Kong's Elevated Walkways Become Public Open Spaces. Asian J. Environ. Stud. 5, 57-72. https://doi.org/10.21834/aje-bs.v5i15.361

Villani, C., Talamini, G., (2019). Patterns of Stationary Activities in the Elevated Pedestrian Networks of High Density Asian Cities: The case of Mong Kok, Hong Kong. Environ. Proc. J. 4. https://doi.org/10.21834/e-bpj.v4i12.1905

Villani, C., Zordan, M., Talamini, G., Cheng, Y.H., (2019). Temporarily Pedestrianized Street in Hong Kong: Governmental Strategy of Implementation and Tactics of Appropriation by Foreign Domestic Workers, in: Proceedings of the AESOP 2019 Congress Book of Papers. The AESOP 2019 Congress, Venice, p. 2559.

Wade, L., (2020). An unequal blow. Science (80-. ). 368, 700-703. https://doi.org/10.1126/science.368.6492.700

Wang, C., Pan, R., Wan, X., Tan, Y., Xu, L., Ho, C.S., Ho, R.C., (2020). Immediate psychological responses and associated factors during the initial stage of the 2019 coronavirus disease (COVID-19) epidemic among the general population in China. Int. J. Environ. Res. Public Health 17, 1729. https://doi.org/10.3390/ijerph17051729

Wang, L., Tosi, M.C., Villani, C., Maroso, S., Pellizer, A., Aymonino, A., Talamini, G., (2018). Walkable Cities in High Density China Livable, Healthy and Sustainable. Tongji University Press, Shanghai.

Wang, W., (2020). Everyday practice in the high density, volumetric Hong Kong: Ambiguity, intensity and life between interfaces. Cities 96, 102462. https://doi.org/10.1016/j.cities.2019.102462

Yin, R.K., (2014). Case Study Research: Design and Methods. SAGE Publications.

Zhang, J., (2020). City \& Society Divided in a connected world: Reflections on COVID 19 from Hong Kong. https://doi.org/10.1111/ciso.12264 